\title{
Beyond protein intake: bushmeat as source of micronutrients in the Amazon
}

\author{
$\underline{\text { Flavia M. Sarti }}^{1}$, Cristina Adams $^{2}, \underline{\text { Carla Morsello }}^{1,3}, \underline{\text { Nathalie van Vliet }}^{4}$, Tatiana Schor $^{5}$, Blanca Yagüe $^{6}$, Leady Tellez $^{6}, \underline{\text { Maria }}$ \\ Paula Quiceno-Mesa ${ }^{7}$ and Daniel Cruz $^{7}$
}

\begin{abstract}
Wild meat is critical for the food security and income of millions of people, especially for poor rural households. Its role as a primary source of macronutrients worldwide has been recognized, but there have been few attempts to evaluate the contribution of bushmeat consumption to micronutrient intake. This is so particularly in the context of nutritional transitions induced by modernization and globalization. Here, we calculated the role of bushmeat as a source of micronutrients in the diets of urban and periurban inhabitants within the Tres Fronteras (Peru, Brazil, Colombia) region in the Amazon. We gathered food intake data from 35 households using 3-day 24-h food recalls combined with food weighing. Additionally, we interviewed 105 households on food consumption frequency. Our results indicate that $14.3 \%$ of the households consumed bushmeat, which represented approximately $32 \%$ of their caloric intake, $72 \%$ of consumed protein, and $77 \%$ of iron. Typically, households consuming bushmeat presented higher a nutritional status, i.e., lower intake of carbohydrates $(-10 \%)$ and higher intake of proteins $(+46 \%)$, iron $(+151 \%)$, and zinc $(+23 \%)$, than households not consuming bushmeat. Most of the sampled households did not achieve standard nutritional requirements for calories (94\%), fiber, vitamin C, or iron (97\%) per adult per day. None of the households achieved the recommended daily intake for calcium. Households consuming bushmeat consumed statistically significantly higher levels of iron, zinc, and vitamin $\mathrm{C}$ than households that did not eat bushmeat. The latter consumed an excess of $31 \%$ calories from processed foods per adult per day, and lower amounts of iron $(-60 \%)$ and zinc $(-19 \%)$. We argue that households not consuming bushmeat are at greater risk of anemia in the short run and other chronic health problems in the long run.
\end{abstract}

Key Words: Amazon; bushmeat; conservation; food intake; micronutrients; nutrition

\section{INTRODUCTION}

Wildlife consumption is critical for ensuring the food security and income of millions of people in tropical regions worldwide, especially for poor rural households (Nasi et al. 2008), regardless of modernization and globalization of food habits (Popkin 2001). Bushmeat hunting and consumption has increased in the last decades in rural communities and urban centers because of increased access to forests and for-profit bushmeat trade (MilnerGulland et al. 2003, Nasi et al. 2008). This has led to the so called "bushmeat crisis," which not only threatens wildlife but also the food security of indigenous and rural populations most dependent on wild food sources.

There has been growing interest in understanding the sustainability of bushmeat harvesting and factors that affect bushmeat consumption (Bennett and Robinson 2000, Parry et al. 2009, Poulsen et al. 2009, Godoy et al. 2010, Jenkins et al. 2011, Schulte-Herbrüggen et al. 2013). Moreover, there has been increased focus on the importance of bushmeat to local diets and health in tropical African forests (Neumann et al. 2003, Fa et al. 2009, Golden et al. 2011, Vega et al. 2013, Remis and Jost Robinson 2014) and Amazonian forests (Sirén and Machoa 2008, Fonseca and Pezzuti 2013, Tanner et al. 2013).

In the Amazonian region of South America, a wide range of terrestrial and aquatic fauna, including mammals, birds, fish, turtles, insects, and other invertebrates, are traditionally used as food (Dufour 1991, Gragson 1992, Marconi et al. 2002, Fonseca and Pezzuti 2013). Research has also highlighted the importance of bushmeat and fish as important sources of calories as well as protein (Murrieta et al. 2008, Adams et al. 2009). Although fish is one of the main protein sources for Amazonian people (Adams et al. 2009, Parathian and Maldonado 2010, van Holt et al. 2010, Isaac and Almeida 2011), terrestrial wildlife provides a significant amount of calories and essential nutrients, not only protein, but also fat (Redford and Robinson 1991, Townsend 2000, Murrieta and Dufour 2004). Studies of the daily protein intake provided by wild meat and fish to indigenous (Dufour 1991, Sirén and Machoa 2008) and rural (Murrieta et al. 2008, Prates 2010, Piperata et al. 2011a) populations in the Amazonian region have shown that international standard nutrient recommendations are often met and in some cases even exceeded.

Investigations of the role of wild food consumption in the lives of Amazonian peoples date back to the 1950s, when the focus was on the debate whether protein was limiting factor for social evolution. Initial studies attempted to explain the presence and evolution of human societies in the region (Steward 1949, Meggers 1954, Steward and Faron 1959, Lathrap 1968, Linares 1976, Ross 1978, Beckerman 1979, 1994, Chagnon and Hames 1979, Hames 1987, 1989, Hawkes et al. 1982, Johnson and Behrens 1982, Sponsel 1986, Vickers 1988, Feer 1993, Grenand 1993), but only a limited number of studies have investigated bushmeat intake (Dufour 1991, Sirén and Machoa 2008), despite the importance of wild animals to protein and caloric intake.

In some tropical forest areas other than the Amazon, some authors have addressed the importance of wild meat in supplying essential micronutrients to human diets (Golden et al. 2011, Remis and Jost Robinson 2014). Investigating how bushmeat contributes to micronutrient intake is important because animal-source foods (ASFs) are rich in these essential elements given their greater bioavailability than in vegetable sources, and they have a strong association with better growth, cognitive function, activity,

${ }^{1}$ Center for Interdisciplinary Research in Complex Systems, University of São Paulo, ${ }^{2}$ School of Arts, Sciences and Humanities (EACH) and Institute of Energy and Environment (IEE), University of São Paulo, ${ }^{3}$ Institute of Energy and Environment, University of São Paulo, ${ }^{4}$ Center for International Forestry Research (CIFOR), ${ }^{5}$ Geography Department, Universidade Federal do Amazonas, ${ }^{6}$ Independent consultant, ${ }^{7}$ Fundación Science International 
pregnancy outcomes, and morbidity (Neumann et al. 2003, 2013, Grillenberger et al. 2006, Hulett et al. 2014). To address the gap in the literature with regard to Amazonian forest peoples, we assess the contribution of bushmeat consumption to macro- and micronutrient intake and evaluate the potential consequences of limitations in wildlife availability and nutrition transition to the food security of communities in the Amazon region.

In the Amazon, the livelihoods of indigenous and rural communities have been changing recently because of increasing urbanization, income levels, and access to markets (Piperata 2007, 2011a,b, Coimbra et al. 2013, Adams and Piperata 2014). One result has been the worsening of nutritional patterns because of the adoption of food habits based on processed and industrialized products (Piperata 2007, van Holt et al. 2010, Nardoto et al. 2011). The trends in nutrition transition were confirmed in eastern Amazonia by Piperata (2007), showing an increasing proportion of overweight and obesity among adults, significantly related to changes in diet and activity patterns.

Evidence from a recent study in the Amazon region (encompassing areas of Brazil, Colombia, and Peru) shows that, in the transition zones between rural and urban areas, most villages have an abrupt decrease in freshwater fish and bushmeat consumption, with an increase in the consumption of frozen chicken and beef (Nardoto et al. 2011). Notwithstanding, few attempts have been made to evaluate the possible long-term effects of bushmeat consumption on food security and population health in the Amazon (Godoy et al. 2010, Piperata et al. 2011a,b, Tanner et al. 2013).

\section{BACKGROUND}

The Amazon region has been the stage of one the most compelling and influential academic debates about cultural and social evolution and adaptation to tropical forests. Central to the debate were food production systems and human access to macronutrients, primarily calories and proteins. Steward (1949) was the first author to propose a dichotomy between upland and lowland environments of the Amazon region based on limiting environmental factors that were used to explain impaired social complexity in upland forest environments (Steward 1949, Meggers 1954, Steward and Faron 1959). Because animals were never domesticated for food in the pre-Columbian Amazon, access to bushmeat as a source of proteins in the uplands played a central role in the debate.

Subsequently, Lathrap (1968) suggested that animal protein would be the key limiting factor for social evolution, followed by Ross (1978), who expanded the hypothesis by taking into consideration other variables such as animal behavior, ecological attributes, and hunting technology. Other authors such as Chagnon and Hames (1979) and Vickers (1988) agreed on the limited availability of animal protein in the Amazonian uplands, but criticized the lack of longitudinal quantitative data on hunting efforts, population sizes, and growth rates of hunted species and diet variability in previous studies. Beckerman (1979, 1994) argued that animal protein could be substituted by plant protein in cases of scarcity.

During the debate about animal protein as a limiting factor, optimal foraging models and time allocation studies were used to demonstrate that hunting strategies could overcome local scarcity due to age of settlement (Hawkes et al. 1982, Sponsel 1986, Hames 1989), including garden hunting (Linares 1976). Nevertheless, although numerous data were produced on time allocation, energy expenditure, hunting strategies, and sustainable harvesting models (e.g., Hames 1979, Johnson and Behrens 1982, Feer 1993, Grenand 1993), less emphasis was given to bushmeat intake (Dufour 1991, Sirén and Machoa 2008).

The nutritional ecology research that followed the debate, after it was criticized for its environmental determinism (Roosevelt 1993, 1994), confirmed the importance of bushmeat and fish as sources of both calories and proteins (Adams et al. 2009, Adams and Piperata 2014). Studies also showed that the nutritional environment in the Amazon was changing, and investigations were broadened to include contemporary processes such as nutritional transition and food security (Nardoto et al. 2011, Piperata et al. 2011a,b, Adams and Piperata 2014).

\section{METHODS}

\section{Study area}

The study area, known as Tres Fronteras in the Amazon region (Fig. 1), experiences a unimodal-biseasonal rain regime with a dry season from April to September and a rainy season from October to March. The Amazon River reaches its maximum level in May $(1686 \mathrm{~cm})$, and drops to its lowest level in September (445 cm; Peel et al. 2007).

The region contains settlements originating from successive waves of migrants of indigenous, colono, and mestizo origins (INEI/ UNFPA 2010, Suárez-Mutis et al. 2010, van Vliet et al. 2014). Land tenure includes various uses: forest reserves, agroextractivist settlements, national parks, indigenous territories and settlements, illegally occupied areas, and private properties. There is a significant variety of vertebrate fauna, including approximately 150 terrestrial mammal species, 4 aquatic mammal species, and 468 bird species (van Vliet et al. 2014).

The region is representative of recent trends in the Amazon as a whole, including increased rural-urban migration and influx of industrialized products that are responsible for nutrition transition in some communities (Prates 2010, Nardoto et al. 2011). Local towns have a relatively low level of economic development, as indicated by their position in the Human Development Index (approximately 0.6 for the largest cities of the region). A significant proportion of the local population is of indigenous origin (ranging from 28 to $41 \%$ of the population).

We sampled households in two Colombian towns (Leticia $=$ 37,832 inhabitants, Puerto Nariño $=6983$ inhabitants) and three peri-urban communities near Leticia (Kilometro 6, Kilometro 11, and Kilometro 18), as well as three Brazilian towns (Atalaia do Norte $=17,568$ inhabitants, Benjamin Constant $=38,533$ inhabitants, and Tabatinga $=59,684$ inhabitants).

\section{Study design}

A household food intake survey was undertaken as part of a broader study on the importance of bushmeat to food security and local economy (van Vliet et al. 2014). Within the region, we surveyed households within towns in Brazil and Colombia, but not on the Peruvian side of the border because we were unable to establish institutional links there. We surveyed households in urban and peri-urban areas in the larger cities, and households in 
Fig. 1. Map showing the Tres Fronteras study area in the Amazon region of South America.

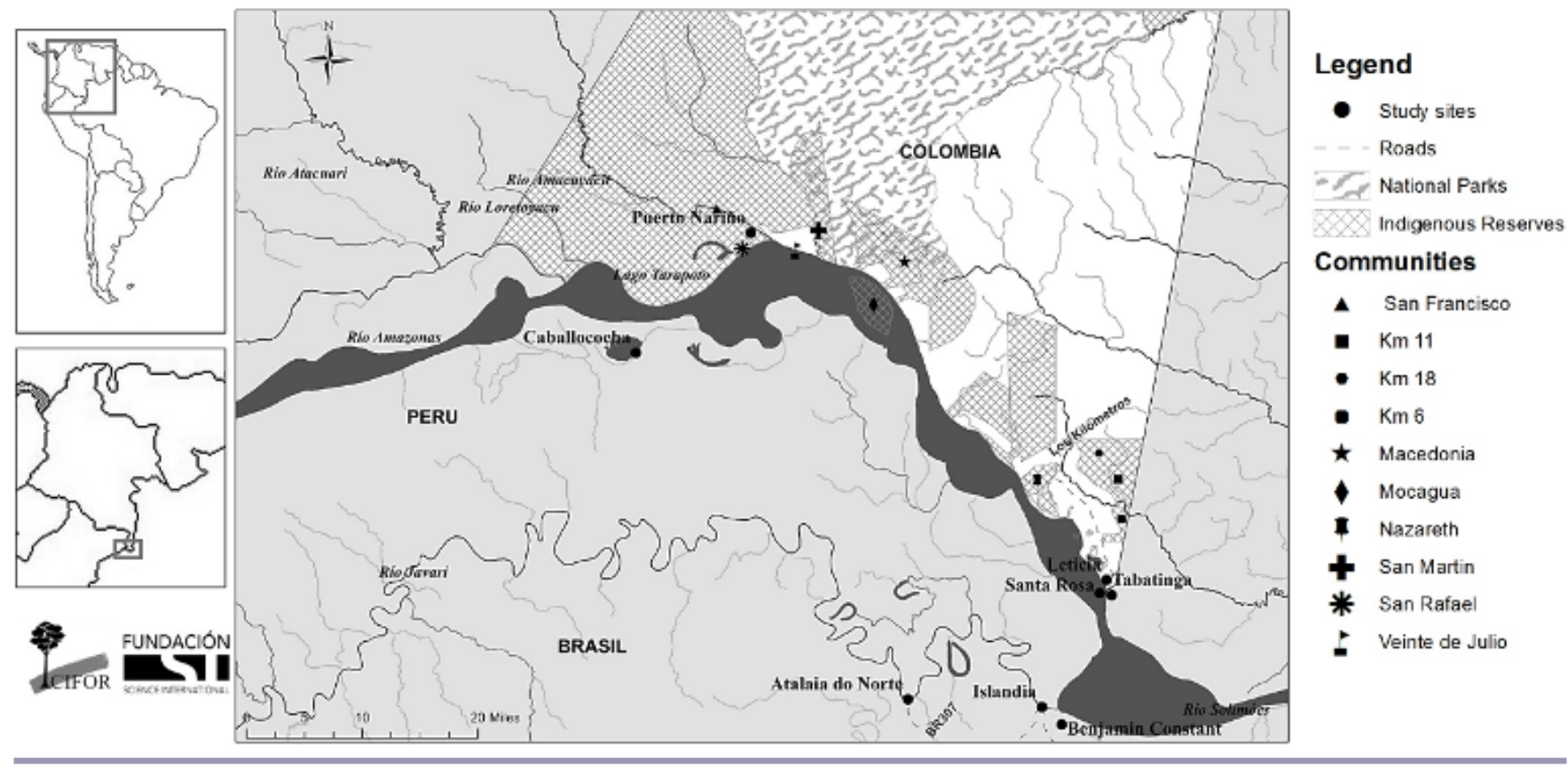

small towns. In the selected towns, we assessed protein consumption among schoolchildren and food consumption frequency in a random sample of households (semi-quantitative) taken from the schoolchildren survey, and we performed an indepth analysis of food intake in a selected sub-sample of households (quantitative). We aimed to include households and individuals from different socioeconomic background and geographical localities in the Amazon region (excluding Peru).

Survey samples were chosen using a nested procedure. The point of departure was a protein and bushmeat consumption survey among schoolchildren from 15 representative rural and urban schools in Brazil and Colombia. We administered questionnaires in the dry $(N=831$, September-October 2012) and rainy season ( $N=865$, February-March 2013). We used the results from these questionnaires to determine household sampling for food consumption frequency and food intake analysis (for detailed results of protein consumption among schoolchildren, see van Vliet et al. 2015b). We interviewed school children following the methods of van Vliet et al. (2015a), which allow for the rapid assessment and monitoring of food consumption patterns among children in relatively large samples because of the few financial and human resources needed. In addition, because it is illegal to consume bushmeat in urban areas, our sampling strategy allowed us to improve the geographical and socioeconomic representativeness of our study.

Our results indicated that almost all $(\sim 99 \%)$ children had consumed animal protein the day before the survey. There was also a strong relationship between household characteristics (especially wealth and location of residence) and bushmeat consumption (van Vliet et al. 2015b). Based on these findings, we structured our sample for the household survey of food frequency and food intake on these two variables. We requested that schoolchildren who participated in the protein consumption survey obtain consent from their parents to include their household in the next research steps. Those families that agreed to participate were asked to provide their household addresses and contact information, and unwilling households were excluded from the database.

The database was then divided in two groups, depending on whether or not they had consumed bushmeat in the previous day. Both groups were subsequently partitioned into three sub-groups according to the number of household assets per person as a proxy of household wealth. Lastly, households were stratified according to school location (small town, peri-urban, or urban). Identical procedures were followed in each country (Colombia and Brazil), resulting in a total of 105 households sampled and interviewed for the food consumption frequency survey, and a sub-sample of 35 households participating in the food intake survey (Fig. 2).

\section{Data collection}

A household was defined as the spatial unit in which food is prepared and consumed. Food consumption away from home was not considered in the survey because there is evidence of imprecision in individuals' estimates of food consumption outside their homes (Margetts and Nelson 2008).

Data on food consumption frequency were collected from 105 households during the dry season (May-July 2013) through interviews on food frequency. The interview comprised a list of food items typically consumed by the population under study, including a quantitative categorization to register the average frequency of consumption of each food item over a certain period of time (Fisberg et al. 2005).

Data on food intake were collected from 35 households during the dry season using a 3-day record of 24-h food recalls combined 
Fig. 2. Flow-chart illustrating the study design. $\mathrm{CB}=$ consuming bushmeat, $\mathrm{NCB}=$ not consuming bushmeat, $\mathrm{HH}=$ households.

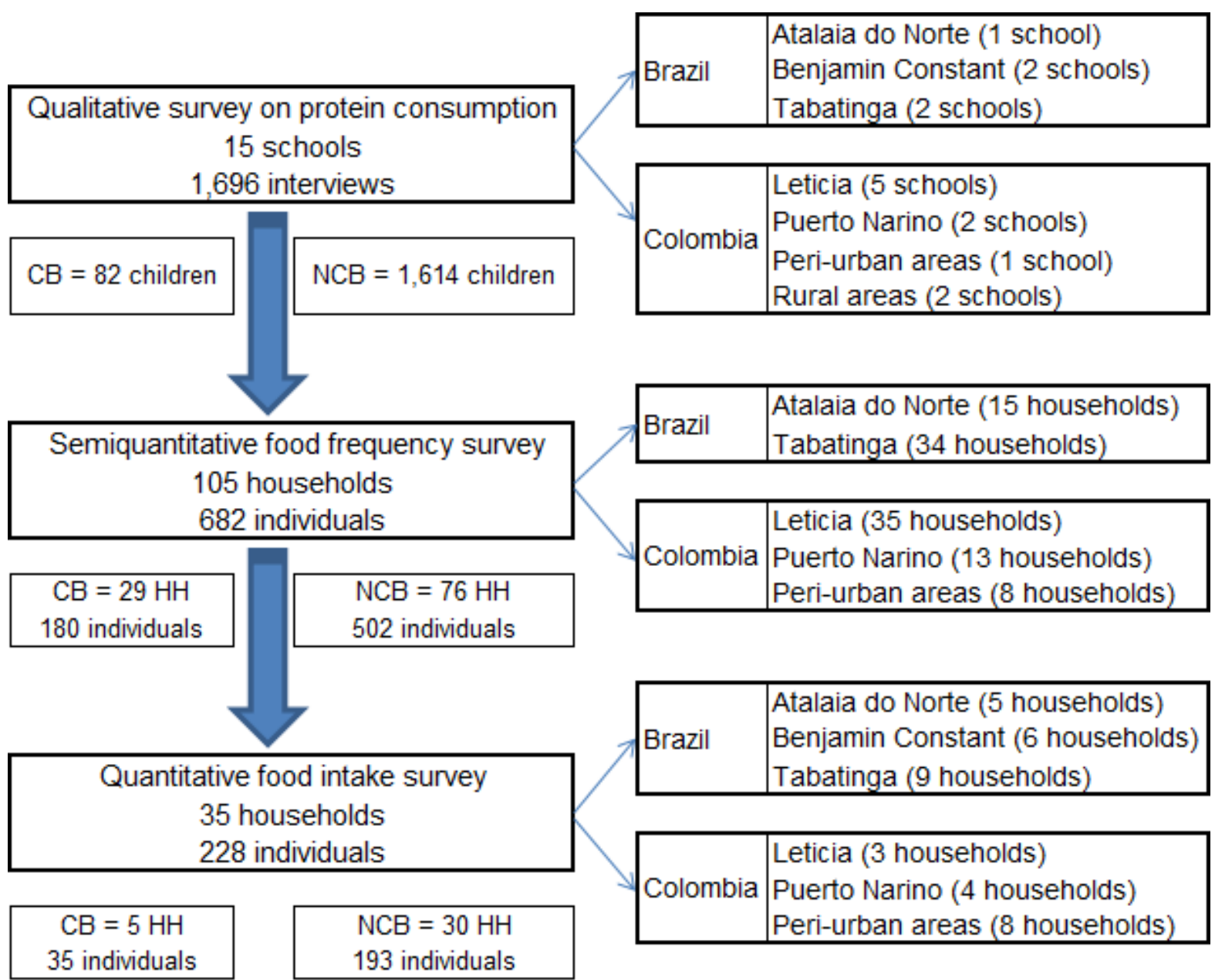

with food item weighing, using the protocols adopted in previous studies (Murrieta 2000, Murrieta and Dufour 2004, Adams et al. 2009). The 3-day record of 24 -h recall combined with food weighing is considered a highly accurate method for food intake evaluations; nevertheless, it is also extremely demanding in terms of research time. Thus, this procedure was associated with the food frequency questionnaire applied to a larger sample of households to allow validation of the representativeness of results obtained in the food intake survey.

During data collection on food intake, semi-structured interviews were carried out with the adult responsible for preparing meals in the household, who was encouraged to register food items consumed by household members during the previous $24 \mathrm{~h}$. Weights in grams of food items were obtained using portable digital scales, and volumes were obtained with plastic jars with scales. Information on the number of participants sharing the meals was also gathered to include guests. Interviews for the food intake survey were conducted during three consecutive days between June and July 2013, recording household food intake from Sunday to Tuesday to include regular working days and weekend days, taking into account that food consumption patterns may vary between weekdays and weekend days (Fisberg et al. 2005).

\section{Data analysis}

Data collected in both surveys (food consumption frequency and food intake) were processed into a database containing information on household socioeconomic characteristics, food consumption frequency, and food intake. The number of household members was converted into adult male equivalent units (AME), according to age and sex (Viacava et al. 1983), to minimize potential underestimation of per capita food consumption (Claro et al. 2010). The AME were summed to indicate the number of adult equivalents in each household (Table 1).

Subsequently, the information on food intake for each household was converted into calories, macronutrients (protein, carbohydrates, and lipids, including fiber and cholesterol), and micronutrients (vitamin C, iron, sodium, and calcium). For this, we used food composition tables from Brazil (Brasil Ministério da Saúde 2002, NEPA/UNICAMP 2011) and Colombia 
Table 1. Household sample characteristics in food intake and food frequency surveys.

\begin{tabular}{|c|c|c|c|c|c|c|c|c|}
\hline \multirow[b]{3}{*}{ Study } & \multirow[b]{3}{*}{ Category } & \multirow[b]{3}{*}{ Subcategory } & \multicolumn{6}{|c|}{ Bushmeat consumption } \\
\hline & & & \multicolumn{2}{|c|}{ Total households } & \multicolumn{2}{|c|}{ Nonconsuming households } & \multicolumn{2}{|c|}{ Consuming households } \\
\hline & & & $N$ & Proportion $(\%)$ & $N$ & Proportion $(\%)$ & $N$ & Proportion $(\%)$ \\
\hline \multicolumn{9}{|c|}{ Food frequency survey } \\
\hline \multirow{2}{*}{\multicolumn{2}{|c|}{ Country }} & Brazil & 49 & 46.7 & 37 & 48.7 & 12 & 41.4 \\
\hline & & Colombia & 56 & 53.3 & 39 & 51.3 & 17 & 58.6 \\
\hline \multirow{3}{*}{\multicolumn{2}{|c|}{ Wealth }} & High & 43 & 41.0 & 31 & 40.8 & 12 & 41.4 \\
\hline & & Medium & 35 & 33.3 & 24 & 31.6 & 11 & 37.9 \\
\hline & & Low & 27 & 25.7 & 21 & 27.6 & 6 & 20.7 \\
\hline \multirow{3}{*}{\multicolumn{2}{|c|}{ Location }} & Small town & 28 & 26.7 & 12 & 15.8 & 16 & 55.2 \\
\hline & & Urban & 73 & 69.5 & 61 & 80.3 & 12 & 41.4 \\
\hline & & Peri-urban & 4 & 3.8 & 3 & 3.9 & 1 & 3.4 \\
\hline \multirow{2}{*}{\multicolumn{2}{|c|}{$\begin{array}{l}\text { Household } \\
\text { members }\end{array}$}} & Individuals & \multicolumn{2}{|c|}{$6.5 \pm 3.3 \dagger$} & \multicolumn{2}{|c|}{$6.6 \pm 3.5 \dagger$} & \multicolumn{2}{|c|}{$6.2 \pm 2.6 \dagger$} \\
\hline & & AME & \multicolumn{2}{|c|}{$3.6 \pm 1.3 \dagger$} & \multicolumn{2}{|c|}{$3.6 \pm 1.4 \dagger$} & \multicolumn{2}{|c|}{$3.5 \pm 1.1 \dagger$} \\
\hline \multicolumn{9}{|c|}{ Food intake Survey } \\
\hline \multirow{2}{*}{\multicolumn{2}{|c|}{ Country }} & Brazil & 20 & 57.1 & 17 & 56.7 & 3 & 60.0 \\
\hline & & Colombia & 15 & 42.9 & 13 & 43.3 & 2 & 40.0 \\
\hline \multirow{3}{*}{\multicolumn{2}{|c|}{ Wealth }} & High & 11 & 31.4 & 10 & 33.3 & 1 & 20.0 \\
\hline & & Medium & 13 & 37.1 & 11 & 36.7 & 2 & 40.0 \\
\hline & & Low & 11 & 31.4 & 9 & 30.0 & 2 & 40.0 \\
\hline \multirow{3}{*}{\multicolumn{2}{|c|}{ Location }} & Small town & 18 & 51.4 & 14 & 46.7 & 4 & 80.0 \\
\hline & & Urban & 15 & 42.9 & 14 & 46.7 & 1 & 20.0 \\
\hline & & Peri-urban & 2 & 5.7 & 2 & 6.7 & 0 & 0.0 \\
\hline \multirow{2}{*}{\multicolumn{2}{|c|}{$\begin{array}{l}\text { Household } \\
\text { members }\end{array}$}} & Individuals & \multicolumn{2}{|c|}{$6.5 \pm 3.1 \dagger$} & \multicolumn{2}{|c|}{$6.4 \pm 3.3 \dagger$} & \multicolumn{2}{|c|}{$7.0 \pm 2.3 \uparrow$} \\
\hline & & AME & \multicolumn{2}{|c|}{$5.1 \pm 2.3 \dagger$} & \multicolumn{2}{|c|}{$5.1 \pm 2.4 \dagger$} & \multicolumn{2}{|c|}{$5.5 \pm 1.6 \dagger$} \\
\hline
\end{tabular}

$\dagger$ Mean \pm SD.

$\$$ Adult male equivalent units.

(Instituto Colombiano de Bienestar Familiar 2014a,b), complemented with the food composition table from the United States Department of Agriculture (2014) in the case of a few food items that were unavailable in the regional tables.

The calories and nutrients consumed at each meal were distributed among the adult equivalents in the household, resulting in values of calories and nutrients per adult. In some cases indicated by the interviewee, invited guests were also computed as participants of a specific meal, using the same adult equivalent conversion method. Then, the nutritional intake per adult equivalent was compared with nutritional requirements proposed for the evaluation of nutritional status (Food and Nutrition Board 1989, Institute of Medicine 1997, 2002). T-tests for equality of means and Levene's test for equality of variances were used to compare the information among households from different countries, wealth levels, and locations of residence.

An analysis of the distribution of calories across the main food groups was also carried out to establish the main contributors in the diet of the two different groups of households. This information was also converted into the number of servings per AME per day to verify the intake adequacy of the main food groups compared to nutritional recommendations for healthy eating (World Health Organization 2003, Harvard School of Public Health 2011). The information on household food consumption frequency was converted into servings to be used as a parameter for evaluating the representativeness of food intake (in servings) reported in the sub-sample of households interviewed in depth.
Lastly, a sensitivity analysis was performed to verify whether differences in nutrient intakes between households consuming and not consuming bushmeat were attributable to bushmeat consumption. For the sensitivity analysis, we simulated a situation in which another protein alterative substitutes completely bushmeat consumption. To do this, we recalculated the nutritional values of food intake per AME by substituting the consumed bushmeat by an equal amount of chicken. The choice of chicken as a potential bushmeat substitute was based on findings from Nardoto et al. (2011), who recently reported high consumption of frozen chicken in Amazonian communities.

\section{RESULTS}

The results obtained for the household food intake survey indicate that households in the sample barely achieve the recommended caloric intake per adult $\left(2900 \mathrm{Kcal} \mathrm{d}^{-1}\right.$ adult $\left.^{-1}\right)$ in the period analyzed. The intake of nutrients considered to be markers of healthy diets, such as fiber, calcium, and vitamin $\mathrm{C}$, were also frequently inferior to the nutritional recommendations for populations adopted worldwide, as a result of the low consumption of fruits and vegetables. Unexpectedly, there were no significant differences in nutrient intake among households from different socioeconomic categories, except for calcium in the medium wealth households, which presented higher intake of the nutrient in comparison to high wealth households. In relation to country and degree of urbanization, there were differences in calories, macronutrients, and some micronutrients, especially zinc and sodium (Table 2). 
Table 2. Nutrient intake per day per adult in the study households according to socioeconomic characteristics and location.

\begin{tabular}{|c|c|c|c|c|c|c|c|c|}
\hline \multirow[t]{2}{*}{ Nutrient } & \multicolumn{2}{|c|}{ Country } & \multicolumn{3}{|c|}{ Wealth } & \multicolumn{3}{|c|}{ Location } \\
\hline & Brazil & Colombia & High & Medium & Low & Small town & Urban & Peri-urban \\
\hline$N$ & 20 & 15 & 11 & 13 & 11 & 18 & 15 & 2 \\
\hline Calories (Kcal) & 1977.85 & $1475.65^{*}$ & 1584.92 & 1987.41 & 1674.67 & 2038.64 & $1489.80^{*}$ & $1324.60 *$ \\
\hline Fiber (g) & 16.67 & 12.19 & 13.95 & 17.79 & 11.96 & 14.83 & 14.41 & 16.57 \\
\hline Calcium (mg) & 434.01 & 379.41 & 319.03 & $507.93^{*}$ & 387.18 & 448.02 & 368.10 & 392.72 \\
\hline Iron $(\mathrm{mg})$ & 9.66 & $5.79 *$ & 6.33 & 7.32 & 10.48 & 9.79 & 6.22 & 5.22 \\
\hline Zinc (mg) & 11.62 & $6.07 *$ & 8.11 & 9.85 & 9.66 & 11.42 & $7.32 *$ & $4.03^{*}$ \\
\hline Sodium (mg) & 4544.30 & $2603.33^{*}$ & 3153.83 & 3981.62 & 3952.98 & 4454.96 & $2956.08^{*}$ & 2702.73 \\
\hline Vitamin C (mg) & 17.56 & 23.55 & 25.40 & 17.66 & 17.76 & 16.69 & 24.00 & 21.93 \\
\hline Cholesterol (mg) & 382.10 & 364.72 & 332.12 & 332.03 & 467.56 & 437.50 & 326.44 & 170.61 \\
\hline Protein $(\mathrm{g})$ & 110.83 & $76.08 *$ & 79.85 & 95.31 & 112.75 & 120.39 & $74.82 *$ & $34.21^{*}$ \\
\hline Lipids (g) & 69.33 & $48.08^{*}$ & 53.08 & 72.42 & 52.94 & 78.26 & $43.56^{*}$ & $22.83^{*}$ \\
\hline Carbohydrates (g) & 223.83 & 183.41 & 195.66 & 236.17 & 182.28 & 208.66 & 198.44 & 247.54 \\
\hline Saturated fatty acids (g) & 18.05 & 13.18 & 13.40 & 18.24 & 15.83 & 19.65 & $12.95^{*}$ & $5.39 *$ \\
\hline $\begin{array}{l}\text { Monounsaturated fatty } \\
\text { acids (g) }\end{array}$ & 22.51 & $14.26^{*}$ & 16.64 & 22.67 & 16.94 & 25.16 & $13.34^{*}$ & $5.58^{*}$ \\
\hline $\begin{array}{l}\text { Polyunsaturated fatty acids } \\
\text { (g) }\end{array}$ & 17.33 & 15.68 & 15.74 & 19.65 & 13.92 & 21.08 & $12.56^{*}$ & $7.00^{*}$ \\
\hline
\end{tabular}

$* P<0.05$, test of equality of means.

In relation to nutrients associated with unhealthy diets (i.e., sodium, cholesterol, and saturated fatty acids), a higher percentage of households in the sample presented excessive intake of sodium and low intake of cholesterol and saturated fatty acids in relation to nutritional recommendations. In the cases of such nutrients, households that registered bushmeat consumption presented nutrient intake that may be considered higher (respectively, $+8,+20$, and $+25 \%$ ) in comparison to households not consuming bushmeat (Table 3 ).

For sodium, both groups of households greatly exceeded the maximum level of recommended intake, whereas for cholesterol and saturated fatty acids, neither group of households reached the maximum level of recommended intake. Daily adult food consumption patterns in households that did not register bushmeat consumption during the survey indicated a higher intake of carbohydrates $(+12 \%)$, and lower intake of proteins $(-32 \%)$, iron $(-60 \%)$, and zinc $(-19 \%)$.

It is worth noting that one of the most frequent food items registered in the food intake survey was manioc (Manihot esculenta). Manioc flour, which represented an average of 1.32 servings ${ }^{-1}$ adult $^{-1}$, was consumed in higher quantity among households consuming bushmeat (Table 4). Manioc is a staple food in the Amazon (Adams et al. 2009) and is usually consumed with fish or bushmeat.

The overall consumption of meats was almost $44 \%$ lower in individuals from households that did not report bushmeat consumption in comparison to the households reporting bushmeat consumption. Moreover, the average daily intake of processed meats was approximately $90 \%$ higher in households that did not consume bushmeat. Furthermore, food items obtained from fishing and hunting were among the main food items among the households surveyed, contributing significant amounts of calories and essential nutrients.

The proportions of fruits and vegetables consumed (number of portions) reached the recommended levels of the World Health
Organization, whose standards suggest at least five food servings consumed per person per day (World Health Organization 2003). The group of fruits and vegetables included açai (Euterpe spp.) and plantain (Musa spp.), two food items that may be considered staple foods in the Amazon region. Açai and plantain represented approximately $90 \%$ of the fruits and vegetables servings consumed among both types of households.

The comparative analysis of the food consumption and food intake surveys showed a connection between the reported frequencies and numbers of servings obtained in 3-day record of 24-h food recalls combined with food items weighing, with regard to the main food items in the habitual diet of the sampled population. Only two food items (manioc and other fruits) presented major differences between the food consumption frequency and food intake survey results among households not consuming bushmeat. In addition, one food item (beans) diverged between the two data sets. The survey comparison indicated an underestimation of food intake per AME in manioc, other fruits, and beans in the food consumption frequency survey.

Bushmeat, fish, and chicken were the main food sources of animal protein in the dietary habits of the communities surveyed. Additionally, there seems to be a potential effect of substitution between bushmeat and fish because households not consuming bushmeat showed higher consumption of fish compared to households reporting bushmeat consumption.

The analysis therefore suggests that food intake among individuals in households not consuming bushmeat may be higher than estimated, especially intake of staple foods with high carbohydrate content (i.e., other fruits including açai, manioc, and manioc flour). Hence, our results based on 3-day 24-h recalls may have underestimated the consumption of carbohydrates and calories in these households. Beans, a food item associated with higher vegetable protein intake, was underestimated in both groups of households, indicating that protein and calorie consumption may be higher than estimated in the food intake survey. 
Table 3. Nutrient intake per day per adult in the study households according to declaration of bushmeat consumption.

\begin{tabular}{|c|c|c|c|c|c|c|c|c|c|c|}
\hline \multirow[t]{2}{*}{ Nutrient } & \multicolumn{3}{|c|}{ Total households } & \multicolumn{3}{|c|}{$\begin{array}{l}\text { Households not consuming } \\
\text { bushmeat }\end{array}$} & \multicolumn{3}{|c|}{$\begin{array}{c}\text { Households consuming } \\
\text { bushmeat }\end{array}$} & \multirow{2}{*}{$\begin{array}{l}\text { Dietary } \\
\text { Reference } \\
\text { Intake }\end{array}$} \\
\hline & Mean & $\mathrm{SD}$ & Adeq $\dagger$ & Mean & $\mathrm{SD}$ & Adeq $\dagger$ & Mean & $\mathrm{SD}$ & Adeq $\dagger$ & \\
\hline Number of households & $35 \%$ & & & $30 \%$ & & & $5 \ddagger$ & & & \\
\hline Calories (Kcal) & 1762.62 & 656.26 & $-39.2 \%$ & 1727.85 & 654.63 & $-40.4 \%$ & 1971.25 & 700.22 & $-32.0 \%$ & 2900 \\
\hline Fiber $(g)$ & 14.75 & 8.94 & $-61.2 \%$ & 15.10 & 9.06 & $-60.3 \%$ & 12.66 & 8.77 & $-66.7 \%$ & 38 \\
\hline Calcium (mg) & 410.61 & 207.74 & $-68.4 \%$ & 408.70 & 191.45 & $-68.6 \%$ & 422.09 & 317.63 & $-67.5 \%$ & 1300 \\
\hline Iron (mg) & 8.00 & 6.13 & $-55.5 \%$ & 6.59 & 3.02 & $-63.4 \%$ & 16.51 & 12.17 & $-8.3 \%$ & 18 \\
\hline Zinc (mg) & 9.24 & 5.48 & $-16.0 \%$ & 8.94 & 5.38 & $-18.7 \%$ & 11.04 & 6.37 & $0.4 \%$ & 11 \\
\hline Sodium (mg) & 3712.46 & 2039.93 & $642.5 \%$ & 3672.46 & 1955.06 & $634.5 \%$ & 3952.46 & 2752.37 & $690.5 \%$ & 500 \\
\hline Vitamin C (mg) & 20.12 & 20.02 & $-77.6 \%$ & 20.77 & 21.20 & $-76.9 \%$ & 16.26 & 11.23 & $-81.9 \%$ & 90 \\
\hline Cholesterol (mg) & 374.65 & 175.19 & $24.9 \%$ & 364.11 & 155.87 & $21.4 \%$ & 437.88 & 280.90 & $46.0 \%$ & 300 \\
\hline Protein (g) & 95.93 & 50.61 & $21.8 \%$ & 89.97 & 41.43 & $20.8 \%$ & 131.72 & 86.38 & $26.7 \%$ & $10-15 \%$ \\
\hline Lipids (g) & 60.22 & 31.01 & $30.7 \%$ & 57.75 & 31.93 & $30.1 \%$ & 75.01 & 21.53 & $34.2 \%$ & $15-30 \%$ \\
\hline Carbohydrates (g) & 206.51 & 102.65 & $46.9 \%$ & 209.59 & 104.40 & $48.5 \%$ & 188.00 & 100.20 & $38.1 \%$ & $55-75 \%$ \\
\hline Saturated fatty acids (g) & 15.96 & 7.82 & $8.2 \%$ & 15.41 & 7.84 & $8.0 \%$ & 19.28 & 7.57 & $8.8 \%$ & $<10 \%$ \\
\hline $\begin{array}{l}\text { Monounsaturated fatty acids } \\
\text { (g) }\end{array}$ & 18.97 & 10.44 & $18.2 \%$ & 18.44 & 10.88 & $17.7 \%$ & 22.18 & 7.30 & $20.5 \%$ & $>6 \%$ \\
\hline $\begin{array}{l}\text { Polyunsaturated fatty acids } \\
\text { (g) }\end{array}$ & 16.62 & 9.57 & & 15.62 & 9.53 & & 22.64 & 8.17 & & \\
\hline
\end{tabular}

$\uparrow$ Adequacy in relation to nutritional recommendations.

+Total number of households.

In contrast, the results obtained for the other food items were highly consistent between data from the food intake sub-sample and the comprehensive sample of the population reporting food consumption frequency. Moreover, data associated with food intake among households that reported bushmeat consumption was highly representative of food consumption frequency registered in the wider sample of households from the region.

In general, the nutritional value of bushmeat consumption per AME represented approximately $32 \%$ of the usual caloric intake and approximately $72 \%$ of protein intake in the households that adopt such practice, being the main food source of iron and zinc for those individuals (Table 5). In relation to nutrients considered markers of unhealthy diets, bushmeat intake represented approximately $73 \%$ of cholesterol in the usual food consumption pattern and $38 \%$ of saturated fatty acids. Although bushmeat did not contribute significantly to sodium intake by itself, most protein based dishes require additional seasoning, especially salt.

The sensitivity analysis showed that bushmeat consumption is highly associated with differences in iron, zinc, and vitamin $\mathrm{C}$ intake. A substitution of bushmeat by the same amount of chicken would represent a substantial decrease in iron (approximately $65 \%$ reduction), zinc (approximately 24\% reduction), and vitamin C (approximately 17\% reduction) content in the diets of individuals otherwise consuming bushmeat (Table 6). Other nutrients influenced by bushmeat substitution in the simulation performed for sensitivity analysis were calcium $(-3 \%)$, cholesterol $(-1 \%)$, monounsaturated fatty acids $(+2 \%)$, and polyunsaturated fatty acids $(+2 \%)$

\section{DISCUSSION}

Our study aim was to analyze the average food consumption patterns among individuals living in urban and peri-urban areas in the Amazon region to identify the nutritional contributions derived from bushmeat intake in their daily diets. The results showed that food consumption patterns in the sampled households are close to the lower acceptable limits of caloric intake and represent an insufficient nutritional intake in relation to the majority of nutrients associated with a healthy diet, especially fiber, vitamin C, calcium, iron, and zinc. In contrast, there was excessive intake of foods with high protein, sodium, and cholesterol content.

One of the main concerns regarding the food consumption profile observed in the sampled households is the lower intake of micronutrients associated with infant growth and development, especially iron and zinc. This may compromise the health status of the population in the region because the lack of micronutrients could generate a vicious cycle of under-nutrition, stunting, and impoverishment (Grillenberger et al. 2006, Lozoff 2007, Zimmermann and Hurrell 2007, da Silva and Begossi 2009). There is evidence in the literature regarding the role of proteins from animal sources in child growth and development, particularly associated with the intake of high-quality proteins, iron, and zinc, in addition to other micronutrients related to human physical and mental development, which present several repercussions in health and productivity in adulthood (Caulfield et al. 2004, Lozoff 2007, Zimmermann and Hurrell 2007). In nutritional terms, the iron and zinc deficiencies registered in our study among individuals not consuming bushmeat are particularly worrying with respect to present and future health effects, especially considering that it may be an outcome of a substitution by other food items with lower nutritive value. A chronic situation of low intake of iron and zinc, potentially in combination with low nutrient bioavailability due to parasitic worms, hemorrhages, and other health problems, may cause iron deficiency anemia (Golden et al. 2011), resulting in deleterious effects in the lean mass formation (Neumann et al. 2013), height (Bandhu et al. 2003, Neumann et al. 2003), cognitive and motor development (Black $2003 a, b$ ), immune response (Ekiz et al. 2005), and behavioral development (Corapci et al. 2010). 
Table 4. Household consumption of main food groups and items per adult equivalent per day (calories and servings) according to declaration of bushmeat consumption.

\begin{tabular}{|c|c|c|c|c|c|c|}
\hline \multirow[t]{2}{*}{ Food groups or items } & \multicolumn{2}{|c|}{ Calories $\dagger$} & \multicolumn{2}{|c|}{ Servings $\dagger$} & \multicolumn{2}{|c|}{ Frequency: } \\
\hline & NCBß & $\mathrm{CB}$ & $\mathrm{NCB}$ & $\mathrm{CB}$ & $\mathrm{NCB}$ & $\mathrm{CB}$ \\
\hline $\bar{N}$ & 30 & 5 & 30 & 5 & 76 & 29 \\
\hline Meat & 555.48 & 986.06 & 2.92 & 5.19 & & \\
\hline Beef & 63.02 & 25.03 & 0.33 & 0.13 & 0.31 & 0.21 \\
\hline Bushmeat & - & 377.44 & - & 1.99 & - & 0.39 \\
\hline Chicken & 186.86 & 363.63 & 0.98 & 1.91 & 0.60 & 0.56 \\
\hline Fish & 230.92 & 192.35 & 1.22 & 1.01 & 0.52 & 0.58 \\
\hline Pork & 22.19 & - & 0.12 & - & 0.05 & 0.01 \\
\hline Processed meat & 52.49 & 27.60 & 0.28 & 0.15 & 0.45 & 0.37 \\
\hline Staples & 579.67 & 485.40 & 4.02 & 3.29 & & \\
\hline Beans & 13.74 & 4.65 & 0.25 & 0.08 & 0.90 & 0.72 \\
\hline Rice & 103.36 & 81.07 & 0.69 & 0.54 & 2.53 & 2.44 \\
\hline Manioc or manioc flour & 186.58 & 210.02 & 1.24 & 1.40 & 2.24 & 2.30 \\
\hline Other starchy foods & 275.99 & 189.66 & 1.84 & 1.26 & 2.53 & 2.44 \\
\hline Fruits and vegetables & 211.14 & 201.82 & 6.29 & 5.93 & & \\
\hline Plantain & 56.03 & 57.36 & 1.60 & 1.64 & 1.50 & 1.94 \\
\hline Other fruits & 148.46 & 140.07 & 4.24 & 4.00 & 1.83 & 1.99 \\
\hline Vegetables & 6.66 & 4.40 & 0.44 & 0.29 & 0.95 & 0.89 \\
\hline Dairy & 16.85 & 46.80 & 0.14 & 0.39 & 1.08 & 0.96 \\
\hline Eggs & 55.68 & 15.72 & 0.29 & 0.08 & 0.58 & 0.55 \\
\hline Other & 271.43 & 321.96 & 3.14 & 3.91 & & \\
\hline Sugary beverages & 14.28 & 6.69 & 0.13 & 0.06 & 0.49 & 0.47 \\
\hline Oils or fats & 145.20 & 213.23 & 1.99 & 2.92 & - & - \\
\hline Sweets or added sugar & 111.95 & 102.05 & 1.02 & 0.93 & 0.60 & 0.53 \\
\hline
\end{tabular}

$\dagger$ Reported data on calories and servings per food groups and food items refer to information obtained in the food intake survey.

$\$$ Reported data on frequency refer to information obtained in the food consumption frequency survey.

$\S$ Households not consuming bushmeat.

|Households consuming bushmeat.

TThe food frequency questionnaire did not include questions related to food items such as oils and fats because their use is associated with the food preparation process.

Furthermore, dietary iron and zinc bioavailability are negatively affected by high intake of food items from vegetable sources (staples such as manioc, corn, and legumes). Our findings therefore suggest that micronutrient deficiencies should be targeted by public health programs in the region, especially programs associated with the promotion of healthy diets (Neumann et al. 2003, Grillenberger et al. 2006). The adoption of healthy eating patterns may generate a virtuous cycle of biological and socioeconomic growth and development that may be potentiated from individuals to households and communities (Fogel 2002).

Another concern regarding the food consumption profiles identified in the sampled households is the prevalence of processed meats, sweets, pasta, sandwiches, and sodas in the meals reported. Such food items present lower nutritional value and reduced protein content in comparison to bushmeat, in addition to their high salt, added sugar, and fat contents. Because the habitual diet in the sampled households combined low ingestion of fiber and vitamins with high ingestion of sodium and lipids, the evidence may be indicative of some worrying aspects of a nutritional transition similar to that reported in several studies showing that part of the Amazon population is gradually substituting bushmeat with frozen chicken produced and transported from other regions, which is traded in the Amazon region in similar questionable sanitary conditions noted elsewhere in the Amazon (Popkin 2001, Piperata 2007, da Silva and Begossi 2009, van Holt et al. 2010, Nardoto et al. 2011, Adams and Piperata 2014).

Nevertheless, reinforcing prior evidence (Redford and Robinson 1991, Townsend 2000, Murrieta and Dufour 2004, Adams et al. 2009, da Silva and Begossi 2009, Parathian and Maldonado 2010, van Holt et al. 2010, Isaac and Almeida 2011), our results showed that food items obtained through fishing and hunting still play an important role of the livelihoods of both groups of households surveyed. The consumption of manioc flour in association with proteins is still a very important staple food among households in the Amazon region, as previously described in the literature, characterizing an adaptive strategy for the survival of traditional communities (Murrieta et al. 1999, Murrieta 2000, Murrieta and Dufour 2004, Adams et al. 2009, da Silva and Begossi 2009).

However, when compared to bushmeat consuming households, households not consuming bushmeat showed poorer nutritional patterns of food intake because of their higher ingestion of food items with high sugar and simple carbohydrate contents, associated with lower consumption of animal proteins. Several circumstances influence bushmeat consumption, including price and availability of bushmeat in comparison to alternative animalsource food (Brashares et al. 2004, Cowlishaw et al. 2005, Nardoto et al. 2011, van Vliet and Mbazza 2011). Prior studies show a nutrition transition in progress in the region, derived from the 
Table 5. Comparison of nutrient intake from bushmeat per meal per day in relation to nutritional value of the meal and usual daily household consumption.

\begin{tabular}{|c|c|c|c|c|c|c|}
\hline \multirow[t]{2}{*}{ Nutrient } & \multicolumn{2}{|c|}{$\begin{array}{l}\text { Households consuming } \\
\text { bushmeat }\end{array}$} & \multicolumn{2}{|c|}{ Bushmeat consumption } & \multicolumn{2}{|c|}{ Nutritional value of bushmeat } \\
\hline & Mean & SD & Mean & SD & Per day $(\%)$ & 3 -day mean $(\%)$ \\
\hline Calories (Kcal) & 1971.25 & 700.22 & 628.25 & 571.34 & 28.5 & 31.8 \\
\hline Fiber $(\mathrm{g})$ & 12.66 & 8.77 & 0 & 0 & 0 & 0 \\
\hline Calcium (mg) & 422.09 & 317.63 & 55.49 & 62.80 & 18.4 & 19.5 \\
\hline Iron (mg) & 16.51 & 12.17 & 25.65 & 28.32 & 74.1 & 139.9 \\
\hline Zinc (mg) & 11.04 & 6.37 & 9.73 & 9.79 & 59.2 & 90.0 \\
\hline Sodium (mg) & 3952.46 & 2752.37 & 175.86 & 164.63 & 6.1 & 5.1 \\
\hline Vitamin C (mg) & 16.26 & 11.23 & 6.01 & 9.47 & 30.8 & 41.1 \\
\hline Cholesterol (mg) & 437.88 & 280.90 & 317.94 & 323.98 & 59.6 & 72.8 \\
\hline Protein $(\mathrm{g})$ & 131.72 & 86.38 & 96.22 & 94.51 & 59.5 & 71.4 \\
\hline Lipids (g) & 75.01 & 21.53 & 24.04 & 20.63 & 30.6 & 34.0 \\
\hline Carbohydrates (g) & 188.00 & 100.20 & 0.22 & 0.59 & 0.2 & 0.1 \\
\hline Saturated fatty acids (g) & 19.28 & 7.57 & 6.86 & 6.20 & 35.0 & 38.4 \\
\hline Monounsaturated fatty acids (g) & 22.18 & 7.30 & 7.44 & 6.52 & 32.8 & 35.5 \\
\hline Polyunsaturated fatty acids (g) & 22.64 & 8.17 & 3.99 & 3.97 & 16.7 & 20.9 \\
\hline
\end{tabular}

lower prices of processed chicken (Piperata 2007, van Holt et al. 2010, Nardoto et al. 2011, Adams and Piperata 2014). Although our data do not allow an analysis of the level of physical activity from labor and other daily activities of individuals in the households surveyed, it is important to note that there is growing evidence for a decreasing level of energy expenditure among Amazon communities (Dufour and Piperata 2008, Piperata et al. 2011b).

We identified a considerably high consumption of processed food items with lower nutritional quality associated with lower bushmeat consumption, i.e., lower protein, iron, and zinc, and higher sodium, carbohydrate, and fat consumption. During the time of our investigation, data on the wild-meat market chain in the Amazon showed that the price of bushmeat was on average $20 \%$ higher than the price of chicken, but cheaper than beef $(-18 \%)$ and pork $(-5 \%$; van Vliet et al. 2014). Although the substitution of chicken for bushmeat may at first glance appear to favor wildlife conservation, there are two likely negative outcomes. The first is a negative effect on food security and thus the health of the local population, with possible long-term effects for development. Second, the consequences of a transition from bushmeat to agribusiness-derived products may have an uncertain effect on conservation because cattle ranching is accompanied by deforestation.

There are some other possibilities for maintaining food security and inducing wildlife conservation by promoting the substitution of bushmeat by other traditional food items such as invertebrates in parts of the Amazon region. Invertebrates present high nutritional quality in terms of proteins, iron, and zinc. Further investigation of the association between bushmeat intake and the nutritional status of urban inhabitants of the Amazon with regard to micronutrients intake, micronutrient bioavailability, and implications for population health would help to improve the understanding of potential long-term consequences of decreasing bushmeat consumption for iron-deficiency anemia and human development.

\section{CONCLUSION}

Households in the Amazon region presented dietary patterns based on consumption of substantial amounts of processed food items with low iron and zinc contents. Our nutritional analysis of the recorded food intake suggested a diet susceptible to anemia (in the short run) and other chronic health problems (in the long run). Moreover, households not consuming bushmeat had significant intake of processed and industrialized foods, evidence which supports prior assumptions of an ongoing nutritional transition in the Amazon region (Piperata 2007, van Holt et al. 2010, Nardoto et al. 2011, Piperata et al. 2011b, Adams and Piperata 2014). Although our survey did not include information on individuals' physical activity levels, there is evidence of decreasing physical activity related to modernization in the Amazon region, especially among women (Dufour and Piperata 2008, Piperata et al. 2011b), indicating some worrying trends for the health of Amazonian communities.

The role of bushmeat, fish, and chicken as the main food sources of animal protein confirm the trends in dietary habits of Amazonian communities shown in previous studies (Dufour 1991, Murrieta et al. 2008, Sirén and Machoa 2008, Adams et al. 2009, Parathian and Maldonado 2010, Prates 2010, van Holt et al. 2010, Isaac and Almeida 2011, Nardoto et al. 2011, Piperata et al. 2011a, Adams and Piperata 2014). Households in both study groups reported higher consumption of such food items within the meats food group. Furthermore, there may be a potential effect of substitution between bushmeat and fish because households not consuming bushmeat showed an increased consumption of fish compared to households reporting bushmeat consumption, a trend already described in the literature (Wilkie and Godoy 2001, da Silva and Begossi 2009, Gonçalves 2015, Pinto 2015).

As an alternative for wildlife conservation, we suggest the creation of public policy initiatives related to the support of tourism in wildlife protected areas in the Amazon region, in association with the promotion of substitution of bushmeat by invertebrates, which constitute food items with high nutritional quality that are culturally accepted among Amazon communities (Marconi et al. 
Table 6. Results of sensitivity analysis performed on nutrient intake per adult equivalent per day for the substitution of bushmeat by chicken.

\begin{tabular}{|c|c|c|c|c|c|c|c|}
\hline \multirow[t]{2}{*}{ Nutrient } & \multicolumn{3}{|c|}{ Real bushmeat consumption } & \multicolumn{3}{|c|}{ Simulated bushmeat consumption } & \multirow[t]{2}{*}{ Difference $(\%)$} \\
\hline & Mean & $\mathrm{SD}$ & Adeq $\dagger(\%)$ & Mean & $\mathrm{SD}$ & Adeq $\dagger(\%)$ & \\
\hline Calories (Kcal) & 1971.25 & 700.22 & -32.0 & 1967.60 & 683.42 & -32.2 & -0.2 \\
\hline Fiber $(\mathrm{g})$ & 12.66 & 8.77 & -66.7 & 12.66 & 8.77 & -66.7 & 0 \\
\hline Calcium (mg) & 422.09 & 317.63 & -67.5 & 408.18 & 318.32 & -68.6 & -3.3 \\
\hline Iron (mg) & 16.51 & 12.17 & -8.3 & 5.82 & 3.20 & -67.7 & -64.8 \\
\hline Zinc (mg) & 11.04 & 6.37 & 0.4 & 8.43 & 4.83 & -23.4 & -23.6 \\
\hline Sodium (mg) & 3952.46 & 2752.37 & 690.5 & 3944.72 & 2749.98 & 688.9 & -0.2 \\
\hline Vitamin C (mg) & 16.26 & 11.23 & -81.9 & 13.46 & 11.64 & -85.0 & -17.2 \\
\hline Cholesterol (mg) & 437.88 & 280.90 & 46.0 & 432.62 & 273.47 & 44.2 & -1.2 \\
\hline Protein (g) & 131.72 & 86.38 & 26.7 & 131.59 & 84.77 & 26.8 & -0.1 \\
\hline Lipids (g) & 75.01 & 21.53 & 34.2 & 74.70 & 22.58 & 34.2 & -0.4 \\
\hline Carbohydrates (g) & 188.00 & 100.20 & 38.1 & 188.00 & 100.20 & 38.2 & 0 \\
\hline Saturated fatty acids (g) & 19.28 & 7.57 & 8.8 & 19.12 & 7.73 & 8.7 & -0.9 \\
\hline Monounsaturated fatty acids (g) & 22.18 & 7.30 & 20.5 & 22.60 & 8.02 & 20.9 & 1.9 \\
\hline Polyunsaturated fatty acids (g) & 22.64 & 8.17 & & 23.12 & 8.42 & & 2.1 \\
\hline
\end{tabular}

$\uparrow$ Adequacy in relation to nutritional recommendations.

2002). Although there were no records regarding entomophagy in our study, invertebrates may represent an important source of nutrients for rural communities in the Amazon (Posey 1978, Dufour 1987, Paoletti et al. 2000) and worldwide (Vantomme et al. 2004, Nasi et al. 2008, Ramos-Elorduy 2009, Durst et al. 2010). Estimates suggest that tropical areas worldwide offer $>1000$ terrestrial species of invertebrates that can be consumed as food (DeFoliart 1997, Marconi et al. 2002, Vantomme et al. 2004, van Huis et al. 2013), and are important sources of energy, protein, and micronutrients (Marconi et al. 2002). Public policies designed to incentivize an increase in insects in the daily food intake may be the key to the sustainability challenges faced by governments dealing with wildlife conservation, without compromising human health. Thus, the absence of bushmeat intake would neither compromise food security nor endanger wildlife through hunting.

We have used caution in interpreting the results, however, because part of the methodology presents some limitations, including the use of household rather than individual food intake data using 24-h recall methods, the sample representativeness for household food intake analysis, and the lack of data collection regarding food intake outside the household. Regarding potential biases arising from intra-household disparities in caloric consumption, we note that these differences are usually derived from the intensity of physical activity associated with labor (Pitt et al. 1990). That is, our adoption of food consumption per AME allowed us to minimize potential estimation errors arising from the use of average individual food consumption.

Considering the sample representativeness, it is possible that some groups may have been underrepresented in the sample because some proportion of the population is unable to send their children to school. Estimates indicate that approximately $14 \%$ of children are considered out-of-school in Colombia, and there are no official estimates for Brazil (UNESCO 2015). However, it is important to note that bushmeat consumption in the Amazon region is a sensitive subject because it is targeted as an illegal activity by the national governments. Thus, a first approach using a qualitative survey of children was considered a reliable source of information to identify groups involved with bushmeat consumption.

Nevertheless, we highlight that the data collection methods used in the survey present consistent values for food intake analysis. The adoption of the 3-day record based on 24-h recall of food consumption combined with food weighing may be an expensive and time-consuming method for long-term monitoring of food intake in large samples. However, the combination of methods, as implemented in our study, is equivalent to methods used in studies of clinical nutrition diagnosis and is considered to improve robustness because it decreases the probability of errors intrinsic to retrospective methods (Fisberg et al. 2005). Furthermore, there was high consistency between data on food intake collected using the 3-day 24-h recall method and the information on household food consumption gathered using food frequency questionnaires. This evidence is indicative of adequate representativeness of the sub-sample analyzed in-depth compared with the larger sample interviewed about food consumption.

Regarding the absence of information on food intake outside of people's homes, we note that food consumption away from home may differ from that within the residence. However, our study was designed to address specifically the importance of healthy diets at the household level, considering that food consumption away from home is low among individuals living in small towns and peri-urban areas, especially considering the substantial differences identified in the Amazon region (Neufeld et al. 2010, Sichieri and Bezerra 2010, Fonseca et al. 2013, Hoffmann 2013). In addition its nutritional value, bushmeat is also linked to important cultural and social values; for this reason, people hunt even when they have alternative sources of nutrition or income. Further discussion of Amazonian communities' cultural values by Bennett and Robinson (2000), Nasi et al. (2008), and Morsello et al. (2015) seeks to shed some light on the socio-cultural dimensions of bushmeat consumption.

We conclude that, in the context of a nutritional transition, food items obtained through fishing and hunting activities play a key 
role in diversifying and enriching modern diets in the Amazon region. The absence of such food items, because environmental policies, wildlife depletion, or prohibitive prices, is of particular concern for human health, particularly for poorer individuals whose choices are limited by purchasing power. In this sense, it is also important to promote better articulation among environmental conservation, food security, and population health.

Responses to this article can be read online at: http://www.ecologyandsociety.org/issues/responses. $\mathrm{php} / 7934$

\section{Acknowledgments:}

We acknowledge the support of the Center for International Forestry Research (CIFOR).

\section{LITERATURE CITED}

Adams, C., R. S. S. Murrieta, A. D. Siqueira, W. A. Neves, and R. A. Sanches. 2009. Bread of the land: the invisibility of manioc in the Amazon. Pages 281-305 in C. Adams, R. S. S. Murrieta, W. A. Neves, and M. Harris, editors. Amazon peasant societies in a changing environment: political ecology, invisibility and modernity in the rainforest. Springer, Dordrecht, The Netherlands. http://dx. doi.org/10.1007/978-1-4020-9283-1 13

Adams, C., and B. A. Piperata. 2014. Ecologia humana, saúde e nutrição na Amazônia. Pages 341-378 in I. C. G. Vieira, P. M. de Toledo, and R. A. O. Santos Jr., editors. Ambiente e sociedade na Amazônia: uma abordagem interdisciplinar. Garamond Universitária, Rio de Janeiro, Brazil.

Bandhu, R., N. Shankar, and O. P. Tandon. 2003. Effect of iron on growth in iron deficient anemic school going children. Indian Journal of Physiology and Pharmacology 47(1):59-66. [online] ULR: http://www.ijpp.com/IJPP\%20archives/2003 47 1/ vol47_no1_orgn_artcl 5.htm.

Beckerman, S. 1979. The abundance of protein in Amazonia: a reply to Gross. American Anthropologist 81(3):533-560. http://dx. doi.org/10.1525/aa.1979.81.3.02a00020

Beckerman, S. 1994. Hunting and fishing in Amazonia: hold the answers, what are the questions? Pages 177-200 in A. Roosevelt, editor. Amazonian Indians: from prehistory to the present. University of Arizona Press, Tucson, Arizona, USA.

Bennett, E. L., and J. G. Robinson. 2000. Hunting for the snark. Pages 1-9 in J. G. Robinson and E. L. Bennett, editors. Hunting for sustainability in tropical forests. Columbia University Press, New York, New York, USA.

Black, M. M. 2003a. Micronutrient deficiencies and cognitive functioning. Journal of Nutrition 133(11):3927S-3931S. [online] URL: http://jn.nutrition.org/content/133/11/3927S.full.

Black, M. M. 2003b. The evidence linking zinc deficiency with children's cognitive and motor functioning. Journal of Nutrition 133(5):1473S-1476S. [online] URL: http://jn.nutrition.org/ content/133/5/1473S.full.
Brashares, J. S., P. Arcese, M. K. Sam, P. B. Coppolillo, A. R. E. Sinclair, and A. Balmford. 2004. Bushmeat hunting, wildlife declines, and fish supply in West Africa. Science 306:1180-1183. http://dx.doi.org/10.1126/science.1102425

Brasil Ministério da Saúde. 2002. Alimentos regionais brasileiros. Brasil Ministério da Saúde, Brasília, Brazil. [online] URL: http://189.28.128.100/nutricao/docs/geral/alimentos_regionais_brasileiros. pdf.

Caulfield, L. E., M. de Onis, M. Blössner, and R. E. Black. 2004. Undernutrition as an underlying cause of child deaths associated with diarrhea, pneumonia, malaria, and measles. American Journal of Clinical Nutrition 80(1):193-198. [online] URL: $\underline{\text { http:// }}$ ajcn.nutrition.org/content/80/1/193.full.

Chagnon, N. A., and R. B. Hames. 1979. Protein deficiency and tribal warfare in Amazonia: new data. Science 203:910-913. http:// dx.doi.org/10.1126/science. 570302

Claro, R. M., R. B. Levy, D. H. Bandoni, and L. Mondini. 2010. Per capita versus adult-equivalent estimates of calorie availability in household budget surveys. Cadernos de Saúde Pública 26 (11):2188-2195. http://dx.doi.org/10.1590/s0102-311x2010001100020

Coimbra, C. E. A., R. V. Santos, J. R. Welch, A. M. Cardoso, M. C. de Souza, L. Garnelo, E. Rassi, M.-L. Follér, and B. L. Horta. 2013. The First National Survey of Indigenous People's Health and Nutrition in Brazil: rationale, methodology, and overview of results. BMC Public Health 13:52-86. http://dx.doi. org/10.1186/1471-2458-13-52

Corapci, F., A. Calatroni, N. Kaciroti, E. Jimenez, and B. Lozoff. 2010. Longitudinal evaluation of externalizing and internalizing behavior problems following iron deficiency in infancy. Journal of Pediatric Psychology 35(3):296-305. http://dx.doi.org/10.1093/ jpepsy/jsp065

Cowlishaw, G., S. Mendelson, and J. M. Rowcliffe. 2005. Evidence for post-depletion sustainability in a mature bushmeat market. Journal of Applied Ecology 42(3):460-468. http://dx.doi. org/10.1111/j.1365-2664.2005.01046.X

da Silva, A. L., and A. Begossi. 2009. Biodiversity, food consumption and ecological niche dimension: a study case of the riverine populations from the Rio Negro, Amazonia, Brazil. Environment, Development and Sustainability 11(3):489-507. http://dx.doi.org/10.1007/s10668-007-9126-Z

DeFoliart, G. R. 1997. An overview of the role of edible insects in preserving biodiversity. Ecology of Food and Nutrition 36 (2-4):109-132. http://dx.doi.org/10.1080/03670244.1997.9991510

Dufour, D. L. 1987. Insects as food: a case study from the Northwest Amazon. American Anthropologist 89(2):383-397. http://dx.doi.org/10.1525/aa.1987.89.2.02a00070

Dufour, D. L. 1991. Diet and nutritional status of Ameridians: a review of the literature. Cadernos de Saúde Pública 7(4):481-502. http://dx.doi.org/10.1590/s0102-311x1991000400003

Dufour, D. L., and B. A. Piperata. 2008. Energy expenditure among farmers in developing countries: What do we know? American Journal of Human Biology 20(3):249-258. http://dx.doi. org/10.1002/ajhb.20764 
Durst, P. B., D. V. Johnson, R. N. Leslie, and K. Shono, editors. 2010. Forest insects as food: humans bite back. Proceedings of a workshop on Asia-Pacific resources and their potential for development. Food and Agriculture Organization, Bangkok, Thailand. [online] URL: http://www.fao.org/docrep/013/i1380e/ i1380e00.htm.

Ekiz, C., L. Agaoglu, Z. Karakas, N. Gurel, and I. Yalcin. 2005. The effect of iron deficiency anemia on the function of the immune system. Hematology Journal 5(7):579-583. http://dx.doi. org/10.4081/thj.2005.1.579

Fa, J. E., L. Albrechtsen, P. J. Johnson, and D. W. Macdonald. 2009. Linkages between household wealth, bushmeat and other animal protein consumption are not invariant: evidence from Rio Muni, Equatorial Guinea. Animal Conservation 12(6):599-610. http://dx.doi.org/10.1111/j.1469-1795.2009.00289.x

Feer, F. 1993. Potential for sustainable hunting and rearing of game animals in tropical forest. Pages 691-708 in C. M. Hladik, H. Pagezy, O. F. Linares, A. Hladik, A. Semple, and M. Hadley, editors. Tropical forests, people and food: biocultural interactions and applications to development. UNESCO and Parthenon, Paris, France.

Fisberg, R. M., B. Slater, D. M. L. Marchioni, and L. A. Martini. 2005. Inquéritos alimentares: métodos e bases científicos. Manole, São Paulo, Brazil.

Fogel, R. W. 2002. Nutrition, physiological capital, and economic growth. Pan American Health Organization and the InterAmerican Development Bank, Washington, D.C., USA. [online] URL: http://www.paho.org/English/HDP/HDD/fogel.pdf.

Fonseca, R. A., and J. C. B. Pezzuti. 2013. Dietary breadth of the animal protein consumed by riverine communities in the Tapajós National Forest, Brazil. Revista de Biología Tropical 61 (1):263-272. http://dx.doi.org/10.15517/rbt.v61i1.11094

Fonseca, Z. Y., G. A. Patriño, and O. F. Herrán. 2013. Malnutrition and food security: a multilevel study. Revista Chilena de Nutrición 40(3):206-215. [online] ULR: http://revistasochinut. org/Revista Nutricion 403/\#/10/.

Food and Nutrition Board. 1989. Recommended dietary allowances. Tenth edition. National Academy Press, Washington, D.C., USA. [online] URL: http://www.nap.edu/catalog/1349/ recommended-dietary-allowances-10th-edition.

Godoy, R., E. A. Undurraga, D. Wilkie, V. Reyes-Garcia, T. Huanca, W. R. Leonard, T. McDade, S. Tanner, V. Vadez, and TAPS Bolivia Study Team. 2010. The effect of wealth and real income on wildlife consumption among native Amazonians in Bolivia: estimates of annual trends with longitudinal household data (2002-2006). Animal Conservation 13(3):265-274. http://dx. doi.org/10.1111/j.1469-1795.2009.00330.x

Golden, C. D., L. C. H. Fernald, J. S. Brashares, B. J. R. Rasolofoniaina, and C. Kremen. 2011. Benefits of wildlife consumption to child nutrition in a biodiversity hotspot. Proceedings of the National Academy of Sciences 108 (49):19653-19656. http://dx.doi.org/10.1073/pnas.1112586108

Gonçalves, P. S. F. 2015. Efeitos da integração à economia de mercado sobre a pesca e o consumo de pescado: estudo em sete comunidades amazônicas do Brasil e da Bolívia. Thesis. Universidade de São Paulo, São Paulo, Brazil.

Gragson, T. L. 1992. Fishing the waters of Amazonia: native subsistence economies in a tropical rain forest. American Anthropologist 94(2):428-440. http://dx.doi.org/10.1525/ aa.1992.94.2.02a00100

Grenand, P. 1993. Fruits, animals and people: hunting and fishing strategies of the Wayãpi of Amazonia. Pages 425-434 in C. M. Hladik, H. Pagezy, O. F. Linares, A. Hladik, A. Semple, and M. Hadley, editors. Tropical forests, people and food: biocultural interactions and applications to development. UNESCO and Parthenon, Paris, France.

Grillenberger, M., C. G. Neumann, S. P. Murphy, N. O. Bwibo, R. E. Weiss, L. Jiang, J. G. A. J. Hautvast, and C. E. West. 2006. Intake of micronutrients high in animal-source foods is associated with better growth in rural Kenyan school children. British Journal of Nutrition 95(2):379-390. http://dx.doi.org/10.1079/ BJN20051641

Hames, R. B. 1979. A comparison of the efficiencies of the shotgun and the bow in neotropical forest hunting. Human Ecology 7(3):219-252. http://dx.doi.org/10.1007/BF00889493

Hames, R. B. 1989. Time, efficiency, and fitness in the Amazonian protein quest. Research in Economic Anthropology 11:43-85.

Harvard School of Public Health. 2011. Healthy eating plate. Harvard University, Cambridge, Massachusetts, USA. [online] URL: http://www.hsph.harvard.edu/nutritionsource/healthy-eatingplatel.

Hawkes, K., K. Hill, and J. F. O'Connell. 1982. Why hunters gather: optimal foraging and the Aché of eastern Paraguay. American Ethnologist 9(2):379-398. http://dx.doi.org/10.1525/ ae.1982.9.2.02a00100

Hoffmann, R. 2013. Comparing the quality of eating out and eating at home in Brazil, 2008-2009. Revista Segurança Alimentar e Nutricional 20(1):1-12. [online] URL: http://www.unicamp.br/ nepa/publicacoes/san/2013/XX 1/docs/comparando-a-alimentacaodentro-e-fora-do-domicilio-no-brasil-em-2008-2009.pdf.

Hulett, J. L., R. E. Weiss, N. O. Bwibo, O. M. Galal, N. Drorbaugh, and C. G. Neumann. 2014. Animal source foods have a positive impact on the primary school test scores of Kenyan schoolchildren in a cluster-randomised, controlled feeding intervention trial. British Journal of Nutrition 111(5):875-886. http://dx.doi.org/10.1017/S0007114513003310

INEI/UNFPA [Instituto Nacional de Estadística e Informática/ Fondo de Población de las Naciones Unidas]. 2010. Perú: análisis etnosociodemográfico de las comunidades nativas de la Amazonía, 1993 y 2007. Dirección Técnica de Demografía e Indicadores Sociales, Lima, Peru. [online] URL: http://proyectos.inei.gob.pe/ web/biblioineipub/bancopub/Est/Lib0902/Libro.pdf.

Institute of Medicine. 1997. Dietary reference intakes for calcium, phosphorus, magnesium, vitamin $D$, and fluoride. National Academy Press, Washington, D.C., USA. [online] URL: http:// www.nap.edu/catalog/5776.html.

Institute of Medicine. 2002. Dietary reference intakes for energy, carbohydrate, fiber, fat, fatty acids, cholesterol, protein, and amino 
acids. National Academy Press, Washington, D.C., USA. [online] URL: http://www.nap.edu/books/0309085373/html.

Instituto Colombiano de Bienestar Familiar. 2014a. Programas y estrategias de bienestar: bienestarina. Instituto Colombiano de Bienestar Familiar, Bogota, Colombia. [online] URL: http:// www.icbf.gov.co/portal/page/portal/PortalICBF/Bienestar/Bienestarina.

Instituto Colombiano de Bienestar Familiar. 2014b. Tabla de composición de alimentos colombianos. Instituto Colombiano de Bienestar Familiar, Bogota, Colombia. [online] URL: http:// alimentoscolombianos.icbf.gov.co/alimentos colombianos/ consulta alimento.asp.

Isaac, V. J., and M. C. Almeida. 2011. El consumo de pescado en la Amazonía brasileña. COPESCAALC Occasional Document 13. Food and Agriculture Organization, Rome, Italy. [online] URL: http://www.fao.org/docrep/014/i2408s/i2408s.pdf.

Jenkins, R. K. B., A. Keane, A. R. Rakotoarivelo, V. Rakotomboavonjy, F. H. Randrianandrianina, H. J. Razafimanahaka, S. R. Ralaiarimalala, and J. P. G. Jones. 2011. Analysis of patterns of bushmeat consumption reveals extensive exploitation of protected species in eastern Madagascar. Plos One 6(12): e27570. http://dx.doi.org/10.1371/journal.pone.0027570

Johnson, A., and C. A. Behrens. 1982. Nutritional criteria in machinguenga food production decisions: a linear-programming analysis. Human Ecology 10(2):167-189. http://dx.doi.org/10.1007/ $\underline{\mathrm{BF} 01531239}$

Lathrap, D. W. 1968. The "hunting" economies of the tropical forest zone of South America: an attempt at historical perspective. Pages 23-29 in R. B. Lee and I. DeVore, editors. Man, the hunter: the first intensive survey of a single, crucial stage of human development-man's once universal hunting way of life. Aldine, Chicago, Illinois, USA.

Linares, O. F. 1976. "Garden hunting" in the American tropics. Human Ecology 4(4):331-349. http://dx.doi.org/10.1007/bf01557917

Lozoff, B. 2007. Iron deficiency and child development. Food and Nutrition Bulletin 28(S4):560S-571S. [online] URL: http://nsinf. publisher.ingentaconnect.com/content/nsinf/fnb/2007/00000028/ A00404s4/art00009.

Marconi, S., P. Manzi, L. Pizzoferrato, E. Buscardo, H. Cerda, D. L. Hernandez, and M. G. Paoletti. 2002. Nutritional evaluation of terrestrial invertebrates as traditional food in Amazonia. Biotropica 34(2):273-280. http://dx.doi.org/10.1111/ j.1744-7429.2002.tb00538.x

Margetts, B. M., and M. Nelson, editors. 2008. Design concepts in nutritional epidemiology. Oxford University Press, New York, New York, USA. http://dx.doi.org/10.1093/acprof: oso/9780192627391.001.0001

Meggers, B. J. 1954. Environmental limitation on the development of culture. American Anthropologist 56(5):801-824. http://dx.doi. org/10.1525/aa.1954.56.5.02a00060

Milner-Gulland, E. J., E. L. Bennett, and the SCB 2002 Annual Meeting Wild Meat Group. 2003. Wild meat: the bigger picture. Trends in Ecology and Evolution 18(7):351-357. http://dx.doi. org/10.1016/S0169-5347(03)00123-X
Morsello, C., B. Yagüe, L. Beltreschi, N. van Vliet, C. Adams, T. Schor, M. P. Quiceno-Mesa, and D. Cruz. 2015. Cultural attitudes are stronger predictors of bushmeat consumption and preference than economic factors among urban Amazonians from Brazil and Colombia. Ecology and Society 20(4):21. http://dx.doi. org/10.5751/ES-07771-200421

Murrieta, R. S. S. 2000. The dilemma of the "Chibé"-eater: food choices, ecology and everyday life among peasant communities in the Lower Amazon, Brazil. Dissertation. University of Colorado, Boulder, Colorado, USA.

Murrieta, R. S. S., M. S. Bakri, C. Adams, P. S. de Souza Oliveira, and R. Strumpf. 2008. Consumo alimentar e ecologia de populações ribeirinhas em dois ecossistemas amazônicos: um estudo comparativo. Revista de Nutrição 21(S1):123S-133S. http://dx.doi.org/10.1590/s1415-52732008000700011

Murrieta, R. S. S., and D. L. Dufour. 2004. Fish and farinha: protein and energy consumption in Amazonian rural communities on Ituqui Island, Brazil. Ecology of Food and Nutrition 43(3):231-255. http://dx.doi.org/10.1080/03670240490447550

Murrieta, R. S. S., D. L. Dufour, and A. D. Siqueira. 1999. Food consumption and subsistence in three caboclo populations on Marajó Island, Amazonia, Brazil. Human Ecology 27(3):455-475. http://dx.doi.org/10.1023/A:1018779624490

Nardoto, G. B., R. S. S. Murrieta, L. E. G. Prates, C. Adams, M. E. P. E. Garavello, T. Schor, A. de Moraes, F. D. Rinaldi, J. G. Gragnani, E. A. F. Moura, P. J. Duarte-Neto, and L. A. Martinelli. 2011. Frozen chicken for wild fish: nutritional transition in the Brazilian Amazon region determined by carbon and nitrogen stable isotope ratios in fingernails. American Journal of Human Biology 23(5):642-650. http://dx.doi.org/10.1002/ajhb.21192

Nasi, R., D. Brown, D. Wilkie, E. Bennett, C. Tutin, G. van Tol, and T. Christophersen. 2008. Conservation and use of wildlifebased resources: the bushmeat crisis. CBD Technical Series 33. Secretariat of the Convention on Biological Diversity, Montreal, Canada, and Center for International Forestry Research, Bogor, Indonesia. [online] ULR: https://www.cbd.int/doc/publications/ cbd-ts-33-en.pdf.

NEPA/UNICAMP [Núcleo de Estudos e Pesquisas em Alimentação/Universidade Estadual de Campinas]. 2011. Tabela Brasileira de composição de alimentos (TACO). Version 4. NEPA/ UNICAMP, Campinas, Brazil. [online] URL: http://www. unicamp.br/nepa/taco/tabela.php?ativo=tabela.

Neufeld, L., M. Rubio, L. Pinzón, and L. Tolentino. 2010. Nutrición en Colombia: estrategia de país 2011-2014. World Bank, Washington, D.C., USA. [online] URL: http://www.piaschile.cl/ wp-content/uploads/2015/04/Nutricion-en-Colombia-Estrategiade-pa $\%$ C3\%ADs-2011-20141.pdf.

Neumann, C. G., N. O. Bwibo, S. P. Murphy, M. Sigman, S. Whaley, L. H. Allen, D. Guthrie, R. E. Weiss, and M. W. Demment. 2003. Animal source foods improve dietary quality, micronutrient status, growth and cognitive function in Kenyan school children: background, study design and baseline findings. Journal of Nutrition 133(11):3941S-3949S. [online] URL: http:// in.nutrition.org/content/133/11/3941S.full. 
Neumann, C. G., L. Jiang, R. E. Weiss, M. Grillenberger, C. A. Gewa, J. H. Siekmann, S. P. Murphy, and N. O. Bwibo. 2013. Meat supplementation increases arm muscle area in Kenyan schoolchildren. British Journal of Nutrition 109(7):1230-1240. http://dx.doi.org/10.1017/S0007114512003121

Paoletti, M. G., E. Buscardo, and D. L. Dufour. 2000. Edible invertebrates among Amazonian indians: a critical review of disappearing knowledge. Environment, Development and Sustainability 2(3-4):195-225. http://dx.doi.org/10.1023/A:1011461907591

Parathian, H. E., and A. M. Maldonado. 2010. Humannonhuman primate interactions amongst Tikuna people: perceptions and local initiatives for resource management in Amacayacu in the Colombian Amazon. American Journal of Primatology 72(10):855-865. http://dx.doi.org/10.1002/ajp.20816

Parry, L., J. Barlow, and C. A. Peres. 2009. Hunting for sustainability in tropical secondary forests. Conservation Biology 23(5):1270-1280. http://dx.doi.org/10.1111/j.1523-1739.2009.01224. $\underline{\mathrm{X}}$

Peel, M. C., B. L. Finlayson, and T. A. McMahon. 2007. Updated world map of the Köppen-Geiger climate classification. Hydrology and Earth System Sciences 11:1633-1644. http://dx. doi.org/10.5194/hess-11-1633-2007

Pinto, M. A. T. 2015. A caça e a pesca na beira de Tabatinga: um estudo do mercado de recursos naturais na tríplice fronteira BrasilColômbia-Peru. Thesis. Universidade Federal do Amazonas, Manaus, Brazil.

Piperata, B. A. 2007. Nutritional status of Ribeirinhos in Brazil and the nutrition transition. American Journal of Physical Anthropology 133(2):868-878. http://dx.doi.org/10.1002/ajpa.20579

Piperata, B. A., S. A. Ivanova, P. Da-Gloria, G. Veiga, A. Polsky, J. E. Spence, and R. S. S. Murrieta. 2011a. Nutrition in transition: dietary patterns of rural Amazonian women during a period of economic change. American Journal of Human Biology 23 (4):458-469. http://dx.doi.org/10.1002/ajhb.21147

Piperata, B. A., J. E. Spence, P. Da-Gloria, and M. Hubbe. 2011 . The nutrition transition in Amazonia: rapid economic change and its impact on growth and development in Ribeirinhos. American Journal of Physical Anthropology 146(1):1-13. http://dx. doi.org/10.1002/ajpa.21459

Pitt, M. M., M. R. Rosenzweig, and N. Hassan. 1990. Productivity, health, and inequality in the intrahousehold distribution of food in low-income countries. American Economic Review 80(5):1139-1156.

Popkin, B. M. 2001. The nutrition transition and obesity in the developing world. Journal of Nutrition 131(3):871S-873S. [online] URL: http://jn.nutrition.org/content/131/3/871S.full.

Posey, D. A. 1978. Ethnoentomological survey of Amerind groups in lowland Latin America. Florida Entomologist 61 (4):225-229. [online] URL: http://journals.fcla.edu/flaent/article/ view/57319/54998.

Poulsen, J. R., C. J. Clark, G. Mavah, and P. W. Elkan. 2009. Bushmeat supply and consumption in a tropical logging concession in northern Congo. Conservation Biology 23 (6):1597-1608. http://dx.doi.org/10.1111/j.1523-1739.2009.01251. $\underline{\mathrm{x}}$
Prates, L. E. G. 2010. Análisis comparativo de la calidad de vida biológica de tres comunidades caboclas de la región del Alto Solimões, Amazonia brasilera. Thesis. Universidad Nacional de Colombia (Sede Amazonia), Leticia, Colombia.

Ramos-Elorduy, J. 2009. Anthropo-entomophagy: cultures, evolution and sustainability. Entomological Research 39 (5):271-288. http://dx.doi.org/10.1111/j.1748-5967.2009.00238.x

Redford, K. H., and J. G. Robinson. 1991. Subsistence and commercial uses of wildlife in Latin America. Pages 6-23 in J. G. Robinson and K. H. Redford, editors. Neotropical wildlife use and conservation. University of Chicago Press, Chicago, Illinois, USA.

Remis, M. J., and C. A. Jost Robinson. 2014. Examining shortterm nutritional status among BaAka foragers in transitional economies. American Journal of Physical Anthropology 154 (3):365-375. http://dx.doi.org/10.1002/ajpa.22521

Roosevelt, A. C. 1993. The rise and fall of the Amazonian chiefdoms. L'Homme 33(126-128):255-283.

Roosevelt, A. C. 1994. Amazonian anthropology: strategy for a new synthesis. Pages 1-29 in A. Roosevelt, editor. Amazonian indians from prehistory to present: anthropological perspectives. University of Arizona Press, Tucson, Arizona, USA.

Ross, E. B. 1978. Food taboos, diet, and hunting strategy: the adaptation to animals in Amazon cultural ecology. Current Anthropology 19(1):1-36. http://dx.doi.org/10.1086/201999

Schulte-Herbrüggen, B., G. Cowlishaw, K. Homewood, and J. M. Rowcliffe. 2013. The importance of bushmeat in the livelihoods of West African cash-crop farmers living in a faunally-depleted landscape. Plos One 8(8): e72807. http://dx.doi.org/10.1371/ journal.pone.0072807

Sichieri, R., and I. N. Bezerra. 2010. Characteristics and spending on out-of-home eating in Brazil. Revista de Saúde Pública 44 (2):221-229.

Sirén, A., and J. Machoa. 2008. Fish, wildlife, and human nutrition in tropical forests: a fat gap? Interciencia 33(3):186-193.

Sponsel, L. E. 1986. Amazon ecology and adaptation. Annual Review of Anthropology 15:67-97. http://dx.doi.org/10.1146/ annurev.an.15.100186.000435

Steward, J. H. 1949. South American cultures: an interpretative summary. Pages 669-772 in J. H. Steward, editor. Handbook of South American Indians. Smithsonian Institution, Washington, D.C., USA.

Steward, J. H., and L. C. Faron. 1959. Native peoples of South America. McGraw-Hill, New York, New York, USA.

Suárez-Mutis, M. C., C. M. Mora Cárdenas, L. P. Pérez Reyes, and P. C. Peiter. 2010. Interacciones transfronterizas y salud en la frontera Brasil-Colombia-Perú. Revista Mundo Amazónico 1:243-266. http://dx.doi.org/10.5113/ma.1.10268

Tanner, S., A. Rosinger, W. R. Leonard, V. Reyes-García, and Taps Bolivia study team. 2013. Health and adult productivity: the relation between adult nutrition, helminths, and agricultural, hunting, and fishing yields in the Bolivian Amazon. American Journal of Human Biology 25(1):123-130. http://dx.doi. org/10.1002/ajhb.22350 
Townsend, W. R. 2000. The sustainability of subsistence hunting by the Sirionó Indians of Bolivia. Pages 267-281 in J. G. Robinson and E. L. Bennett, editors. Hunting for sustainability in tropical forests. Columbia University Press, New York, New York, USA.

UNESCO [United Nations Educational, Scientific and Cultural Organization]. 2015. UNESCO eAtlas of out-of-school children in Brazil and Colombia. UNESCO, Montreal, Canada. [online] URL: http://tellmaps.com/uis/oosc/.

United States Department of Agriculture. 2014. National nutrient database for standard reference: version SR26. USDA, Washington, D.C., USA. [online] URL: http://www.ars.usda.gov/ Services $/$ docs. htm .docid $=23634$.

van Holt, T., W. R. Townsend, and P. Cronkleton. 2010. Assessing local knowledge of game abundance and persistence of hunting livelihoods in the Bolivian Amazon using consensus analysis. Human Ecology 38(6):791-801. http://dx.doi.org/10.1007/ s10745-010-9354-y

van Huis, A., J. Van Itterbeeck, H. Klunder, E. Mertens, A. Halloran, G. Muir, and P. Vantomme. 2013. Edible insects: future prospects for food and feed security. FAO Forestry Paper 171. FAO, Rome, Italy. [online] URL: http://www.fao.org/docrep/018/ i3253e/i3253e.pdf.

van Vliet, N., and P. Mbazza. 2011. Recognizing the multiple reasons for bushmeat consumption in urban areas: a necessary step toward the sustainable use of wildlife for food in Central Africa. Human Dimensions of Wildlife 16(1):45-54. http://dx.doi. org/10.1080/10871209.2010.523924

van Vliet, N., C. Nebesse, and R. Nasi. 2015a. Bushmeat consumption among rural and urban children from Province Orientale, Democratic Republic of Congo. Oryx 49(1):165-174. http://dx.doi.org/10.1017/S0030605311000202

van Vliet, N., M. Quiceno-Mesa, D. Cruz-Antia, L. Tellez, C. Martins, E. Haiden, M. Oliveira, C. Adams, C. Morsello, L. Valencia, T. Bonilla, B. Yagüe, and R. Nasi. 2015b. From fish and bushmeat to chicken nuggets: the nutrition transition in a continuum from rural to urban settings in the Tri Frontier Amazon region. Ethnobiology and Conservation 4: 6. http://dx. doi.org/10.15451/ec2015-7-4.6-1-12

van Vliet, N., M. P. Quiceno-Mesa, D. Cruz-Antia, and B. Yagüe. 2014. Carne de caça e segurança alimentar na zona da tríplice fronteira amazônica (Colômbia, Peru e Brasil). CGIAR, USAID, CIFOR, Fundação Si, UFAM, and Fundação Omacha, Bogota, Colombia. [online] URL: http://www.cifor.org/publications/ pdf_files/Books/BVanVliet1401P.pdf.

Vantomme, P., D. Göhler, and F. N'Deckere-Ziangba. 2004. Contribution of forest insects to food security and forest conservation: the example of caterpillars in central Africa. Wildlife Policy Briefing 3. ODI, London, UK.

Vega, M. G., B. Carpinetti, J. Duarte, and J. E. Fa. 2013. Contrasts in livelihoods and protein intake between commercial and subsistence bushmeat hunters in two villages on Bioko Island, Equatorial Guinea. Conservation Biology 27(3):576-587. http:// dx.doi.org/10.1111/cobi.12067
Viacava, F., C. M. P. Figueiredo, and W. A. Oliveira. 1983. A desnutrição no Brasil: uma análise do Estudo Nacional da Despesa Familiar (IBGE 74-75) para o Nordeste, Estado de São Paulo e Estado do Rio de Janeiro. FINEP/Ed. Vozes, Rio de Janeiro, Brazil.

Vickers, W. T. 1988. Game depletion hypothesis of Amazonian adaptation: data from a native community. Science 239:1521-1522. http://dx.doi.org/10.1126/science.3353699

Wilkie, D. S., and R. A. Godoy. 2001. Income and price elasticities of bushmeat demand in lowland Amerindian societies. Conservation Biology 15(3):761-769. http://dx.doi.org/10.1046/ j.1523-1739.2001.015003761.x

World Health Organization. 2003. Diet, nutrition and the prevention of chronic diseases. Report of a Joint WHO/FAO Expert Consultation. WHO/FAO, Geneva, Switzerland. [online] URL: http://www.who.int/dietphysicalactivity/publications/trs916/ en/.

Zimmermann, M. B., and R. F. Hurrell. 2007. Nutritional iron deficiency. Lancet 370(9586):511-520. http://dx.doi.org/10.1016/ s0140-6736(07)61235-5 